\title{
Somaclonal variation: a morphogenetic and biochemical analysis of Mandevilla velutina cultured cells
}

\footnotetext{
M. Maraschin ${ }^{1}$,

J.A. Sugui ${ }^{7}$

K.V. Wood ${ }^{2}$,

C. Bonham ${ }^{2}$,

D.F. Buchi ${ }^{3}$,

M.P. Cantao ${ }^{4}$,

S.G. Carobrez ${ }^{5}$,

P.S. Araujo ${ }^{1}$,

M.L. Peixoto ${ }^{1}$,

R. Verpoorte ${ }^{6}$ and

J.D. Fontana ${ }^{7}$
}

\author{
'Laboratório de M orfogênese e Bioquímica Vegetal, \\ Universidade Federal de Santa Catarina, Florianópolis, SC, Brasil \\ ${ }^{2}$ Department of Biochemistry, Purdue U niversity, West Lafayette, IN, USA \\ ${ }^{3}$ Laboratório de Celula Neoplásica, Universidade Federal do Paraná, Curitiba, PR, Brasil \\ ${ }^{4}$ Laboratório Central de Pesquisa e Desenvolvimento, LACTEC, Curitiba, PR, Brasil \\ 5Laboratório de Microbiologia, Imunologia e Parasitologia, \\ Universidade Federal de Santa Catarina, Florianópolis, SC, Brasil \\ ${ }^{6}$ Leiden/Amsterdam Center for D rug Research, Leiden University, \\ Division of Pharmacognosy, Leiden, The Netherlands \\ ${ }^{7}$ Laboratório de Quimio-Biotecnologia de Biomassa, Universidade Federal do Paraná, \\ Curitiba, PR, Brasil
}

\section{Correspondence \\ M. Maraschin \\ Laboratório de Morfogênese \\ e Bioquímica Vegetal, CCA, UFSC \\ 88049-900 Florianópolis, SC \\ Brasil \\ Fax: + 55-48-331-5400 \\ E-mail: m2@cca.ufsc.br}

Some of these data were presented at the 20th Symposium on Biotechnology for Fuels and Chemicals, $O$ ak Ridge National Laboratory, Gatlinburg, TN, USA, May, 1998.

Received O ctober 24, 2001 Accepted March 19, 2002

\section{Abstract}

Cell cultures of Mandevilla velutina have proved to be an interesting production system for biomass and secondary metabolites able to inhibit the hypotensive activity of bradykinin, a nonapeptide generated in plasma during tissue trauma. The crude ethyl acetate extract of cultured cells contains about 31- to 79-fold more potent anti-bradykinin compounds (e.g., velutinol $A$ ) than that obtained with equivalent extracts of tubers. Somaclonal variation may be an explanation for the wide range of inhibitor activity found in the cell cultures. The heterogeneity concerning morphology, differentiation, carbon dissimilation, and velutinol $A$ production in $M$. velutina cell cultures is reported. Cell cultures showed an asynchronous growth and cells in distinct developmental stages. Meristematic cells were found as the major type, with several morphological variations. Cell aggregates consisting only of meristematic cells, differentiated cells containing specialized cell structures such as functional chloroplasts (cytodifferentiation) and cells with embryogenetic characteristics were observed. The time course for sucrose metabolism indicated cell populations with significant differences in growth and metabolic rates, with the highest biomass-producing cell line showing a cell cycle $60 \%$ shorter and a metabolic rate $33.6 \%$ higher than the control ( $\mathrm{F}_{2}$ cell population). MALDI-TOF mass spectrometric analysis of velutinol $A$ in selected cell lines demonstrated the existence of velutinol $A$ producing and nonproducing somaclones. These results point to a high genetic heterogeneity in general and also in terms of secondary metabolite content.

\section{Key words}

- Mandevilla velutina

- Secondary metabolism

- Plant cell cultures

- Somaclonal variation

- Phytosteroid

- Anti-bradykinin compounds 


\section{Introduction}

Mandevilla velutina (Apocynaceae) is a plant native to Brazil and in several centralwestern regions folk medicine prescribes the use of infusion or alcoholic extracts of its tuber for the treatment of inflammatory states, including those caused by Bothrops jararaca snake bites. The tubers are a source of bioactive compounds able to selectively antagonize the hypotensive activity of bradyki$\operatorname{nin}(\mathrm{BK})$ and other kinins (1). These anti-BK compounds are secondary metabolites chemically characterized as triterpenoids, e.g., velutinol $A$ (2). However, no significant amounts ( 0.001 to $0.0001 \%$, fresh weight) were found in crude plant extracts $(3,4)$. Recently, a patent covering velutinol $A$ and its glycosylated derivatives was issued in Canada (Canadian Patent No. 70857-228, September, 1998; 5), but large-scale biomass production by conventional methods seems not to be economically feasible.

As an alternative method to the destructive exploitation of native plant populations, in vitro cell culture of $M$. velutina was adopted (6). The extraction of the bioactive compounds with ethyl acetate from cultured cells yielded crude extracts with an anti-BK action about 31- to 79-fold more potent than that obtained with extract of tubers of the plant (3). This result indicated the potential of this method for obtaining the anti-BK compounds. Somaclonal variation, a common phenomenon in plant cell cultures, characterized by phenotypic variation of either genetic or epigenetic origin, may be an explanation for the wide range of inhibitor activity found. Accordingly, somaclonal variation can be either an advantage (variability increase) or disadvantage (loss of stability of cell lines), depending on the aim of the study (7-9). However, it has become apparent that, rather than being an unexplainable aberration in an otherwise uniform cell proliferation process, the appearance of variants in cell cultures may be a routine occurrence for certain types of plants or specific explant sources. Since all cells of an organism are derived from a single cell, it has been assumed that plants derived from cells of a donor plant would yield identical individuals. Nonetheless, studies on somaclonal variation have indicated that clonal uniformity is now recognized as the exception rather than the rule $(10,11)$. Recently, quantitative analyses of velutinol $A$ and its glycosylated form (MV 8612) revealed the occurrence of higher content in cell culture extracts when compared to the native plant (12).

Since somaclonal variants result, by definition, from genetic changes ultimately caused by inheritance (13), several critical analyses of this subject have been conducted focusing on the phenotypic, genetic (e.g., aneuploidy, polyploidy, or mixoploidy), cytogenetic and molecular (DNA methylation) alterations found in plant cells and/or tissues in crop breeding programs (8). Several studies have shown that somaclonal variation can be assessed by analysis of phenotype, chromosome number and structure, proteins or direct DNA evaluation of plants (14). The types of variation that are frequently observed may differ from species to species, and it is often difficult to determine the genetic nature of the observed variation (15). However, one should keep in mind that the correspondence between changes at the phenotypic and cytological/molecular level should be considered, since good correlation might not be found between the extent of mutations (molecular level) and phenotypic changes (14). Thus, in the present state of knowledge, we are able to exploit somaclonal variation, but we are still unable to control it (16).

In contrast, analyses of the occurrence of variants in plant cell cultures concerning biochemical phenotype have been undertaken to a lesser extent. It has been recognized that this phenomenon may provide a source for useful variation, which can form the basis for the development of plant cell 
lines with characteristics of interest even on an industrial scale. As an example, we may mention the production of shikonin from Lithospermum erythrorhizon (17), of berberine from Coptis japonica (18), and of ginsenosides from Panax ginseng (19). Thus, the information about somaclonal variability can be considered fundamental to studies concerning the production of secondary metabolites (7).

The in vitro screening and selection of $M$. velutina somaclones with a high potential for anti-BK production could be done on a chemical basis, taking into account the content of the triterpenoids of interest (13). However, the objective of the present study is to investigate the phenotypic heterogeneity of $M$. velutina cell cultures in a broader sense, taking into account their morphological and metabolic profiles, using light and scanning electron microscopy and growth analysis by the determination of the rate of metabolism of sugars by the cell populations. Furthermore, an investigation concerning secondary metabolites of interest in selected cell lines is reported. In fact, the improvement of the yield of velutinol $A$ in $M$. velutina cell cultures is currently the bottleneck which remains to be overcome before the application of this biotechnological system on a commercial scale.

\section{Material and Methods}

\section{Cell line cultures}

Primary callus cultures were obtained using nodal segments ( $~ 8 \mathrm{~mm}$ long; 6.5-8.0 $\mathrm{mg}$ ) from a single 4-month-old plantlet cultured in vitro, native to the Cerrado ecosystem (Coromandel, MG, Brazil), on semisolid MS medium (20) supplemented with 2 $\mathrm{mg} / \mathrm{l}$ 2,4-dichlorophenoxyacetic acid, $2 \mathrm{mg} / \mathrm{l}$ 6-benzylaminopurine, and $3 \mathrm{mg} / \mathrm{l}$ 6-furfurylaminopurine $\left(\mathrm{MC}_{24}\right.$ medium; 12). The cell lines were set up by a classical method (cellaggregate cloning; 7), selecting high bio- mass-producing clones from regular subcultures (28 days). Briefly, cell aggregates ( 3 $\mathrm{mm}$ in diameter) were subcultured from a single cell colony 28 days after inoculation onto filter paper (21) in contact with liquid $\mathrm{MC}_{24}$ medium. The cultures were kept at 24 $\pm 1^{\circ} \mathrm{C}$, 16 -h photoperiod, $31.5 \mu \mathrm{mol}$ photons $\mathrm{m}^{2} \mathrm{~s}^{-1}$ (Philips TLF 33), and $85-90 \%$ relative humidity. Cell growth biomass was monitored daily by visual inspection for 28 days, followed by transferring ca. $0.1 \mathrm{~g}$ of cells of the higher biomass-producing clones selected to fresh semi-solid $\mathrm{MC}_{24}$ culture medium. From each selected cell line, $0.5 \mathrm{~g}$ of 21-dayold cells were subcultured in $\mathrm{MC}_{24}$ liquid medium to obtain cell suspension cultures as previously described (12). Cell suspensions were maintained in 250-ml Erlenmeyer flasks under continuous light $(31.5 \mu \mathrm{mol}$ photons $\mathrm{m}^{2} \mathrm{~s}^{-1}$, Philips TLF 33) and shaking at 110 rpm at $24 \pm 1^{\circ} \mathrm{C}$. Stock cell line cultures have been cultured according to the above conditions for eight years in our laboratory.

\section{Determination of dissimilation curves}

Growth analysis was performed by determination of dissimilation curves. This is a non-destructive analytical method previously described in detail (22). The dissimilation curves were determined using seven culture flasks $\left(\mathrm{F}_{1}-\mathrm{F}_{7}\right)$, which were weighed at 24-h intervals on a Mettler analytical balance (range: $200 \mathrm{~g}$, accuracy: $0.1 \mathrm{mg}$ ). Inoculated samples (initial cell density $=3 \mathrm{~g}$ cells/flask, accurately weighed) were aseptically collected from a single 21-day-old cell suspension stock-culture, and transferred to 250-ml Erlenmeyer flasks containing $50 \mathrm{ml} \mathrm{MC}_{24}$ culture medium (accurately weighed). Serving as control in respect to water evaporation, three flasks containing only culture medium were also weighed. Silicosen T-32 plugs (Shin-Etsu Polymer Co., Japan, obtained from Simrit Holland B.V., Naarden, The Netherlands) were used to close the flasks in the experiments. The software for 
the analysis of the data was kindly furnished by the Division of Pharmacognosy, Leiden University, Leiden, The Netherlands.

\section{Synchronous cell cultures}

Synchronous cell cultures were obtained by collecting cell samples $(10 \mathrm{ml})$ from a single 30-day-old cell suspension culture (3 $\mathrm{g}$ cells $/ 50 \mathrm{ml}$ culture medium - stationary phase), in order to minimize the effect of any error or variation source, followed by filtration (1.0 $\mathrm{mm}$ in diameter) and inoculation of $0.5 \mathrm{~g}$ cells on $20 \mathrm{ml} \mathrm{MC}_{24}$ semi-solid medium. The growth analysis was carried out by determining the dissimilation curves for two independent cell populations.

\section{Light microscopy}

Samples of $0.5 \mathrm{ml}$ from 21-day-old $M$. velutina cell suspension cultures $\left(2.1 \times 10^{6}\right.$ cells $/ \mathrm{ml}$ ) were collected weekly, centrifuged at $251.5 \mathrm{~g}$ for $5 \mathrm{~min}$ and washed twice with sterile saline solution $(0.85 \% \mathrm{NaCl})$. The cells were resuspended in saline solution and samples were stained with $0.2 \%$ Coomassie brilliant blue R-250 prior to visualization. Data were recorded by micrography under visible light (100X and 400X) using a microscope (Nikon Labophot, Tokyo, Japan) equipped with a Nikon FX-35 camera.

\section{Scanning electron microscopy}

Cells resuspended in saline solution were centrifuged at $1062 \mathrm{~g}$ for $5 \mathrm{~min}$ and washed extensively with $0.1 \mathrm{M}$ sodium cacodylate buffer, $\mathrm{pH} 7.2$, followed by a $2 \%$ glutaraldehyde/2-h dark treatment. Samples were washed twice with sodium cacodylate buffer, resuspended in $1 \% \mathrm{OsO}_{4} / 15 \mathrm{~min}$ in the dark and washed again (three times) in buffer. After centrifuging at $1062 \mathrm{~g}$ for $5 \mathrm{~min}$, cells were sequentially treated with EtOH (50, 75, 90 and 100\%, $15 \mathrm{~min} /$ concentration), gold coated. The material was exam- ined with a Philips XL 30 scanning electron microscope operating at $15 \mathrm{kV}$ and data were recorded with a Linhof camera.

\section{Chromatographic analysis of velutinol A}

For the analysis of the steroid velutinol $A$ in selected cell cultures, $150 \mathrm{~g}$ of cells (fresh weight) from 30-day-old cell cultures (inoculum density $=3 \mathrm{~g}$ cells $/ 50 \mathrm{ml}$ culture medium) were collected, lyophilized and stored at $-20^{\circ} \mathrm{C}$. The compound of interest was extracted from lyophilized cells with 2 volumes of ethyl acetate at $4^{\circ} \mathrm{C} / 7$ days. The extract was filtered, concentrated under reduced pressure (crude extract), followed by the isolation of velutinol $A$ by column chromatography on silica gel, using methylene chloride with increasing amounts of ethyl acetate as eluent (23). The presence of the compound in the column effluent was monitored by TLC on silica gel (Kilselgel $60 \mathrm{~F}_{254}$, $0.25 \mathrm{~mm}$, Merck, Darmstadt, Germany), using hexane:diisopropyl ether:acetone (4:4:3) as the solvent system. Detection was performed by first spraying the chromatoplates with anisaldehyde-sulfuric acid, followed by heating at $100^{\circ} \mathrm{C}(3)$.

\section{MALDI-TOF mass spectrometry analysis of velutinol $A$}

For the detection of velutinol $A$ in the organosolvent fraction of the cell lines we carried out matrix-assisted laser desorption/ ionization time-of-flight (MALDI-TOF) mass spectrometry, with a PerSeptive Biosystems (Framingham, MA, USA) Voyager MALDITOF spectrometer as previously described (24). Briefly, ethyl acetate samples concentrated under reduced pressure (crude extract, see above) were first resuspended in a minimum volume of acetone $(\sim 50 \mu \mathrm{l})$ and mixed (1:20) with the freshly prepared matrix $\alpha$ cyano-4-hydroxycinnamic acid $(10 \mathrm{mg} / \mathrm{ml})$, dissolved in $\mathrm{H}_{2} \mathrm{O}$ :trifluoroacetic acid:acetonitrile $(4: 1: 5, v / v / v)$. A $1-\mu l$ aliquot was ap- 
plied to the sample target and allowed to dry prior to mass spectrometry analysis. A nitrogen laser with a $337 \mathrm{~nm}$ output was used and the spectra were taken in the positive-ion mode using an accelerating voltage of 28 $\mathrm{kV}$. The laser power output was set just above the threshold for ion production.

\section{Results and Discussion}

Cell cultures of $M$. velutina showed an asynchronous growth pattern and somaclones in distinct development stages. Typical meristematic cells with a round shape and translucent cytoplasm were found as the major type, especially along the lag phase (Figure 1A,B,E,F). We also observed a tendency to an elongated shape as the cultures entered the exponential growth phase (Figure 1F). Plant cells are naturally asynchronous with respect to the mitotic cycle, and at any time a culture will contain a combination of cells in different cycle phases (25) as described here. The heterogeneity found might be attributed to the fact that the cell cultures did not originate from a single cell (26). In fact, to account for the lack of uniformity in multicellular explants as in this case, it has been suggested that explants derived from sources other than protoplasts be called complex cultures due to their multicellular origin $(27,28)$. Because it is unlikely that any two cell types have exactly the same proliferation rate, even after prolonged culture cell lines often remain highly heterogeneous in cellular constitution. As an example, a wide variation in berberine content of individual cells within a Coptis japonica cell suspension culture was detected by flow cytometric analysis (29). Indeed, it has been recognized that a cultured cell line seems better defined as a population formed by cells having varied characters at the genetic, biochemical, physiological, and morphological levels, with the resulting phenotype of the population being determined by the predominant cell type. Furthermore, the response of the cell types to external stimuli in terms of the biosynthesis of secondary metabolites, for instance, depends upon their morphological and/or physiological state (16). This is because the cell culture environment not only could induce variations in the cultured cells but could also select a particular cell type. So any cell carrying this trait has a selective advantage over the normal ones and the probability to obtain a mutant with a specific trait is highly increased (30).

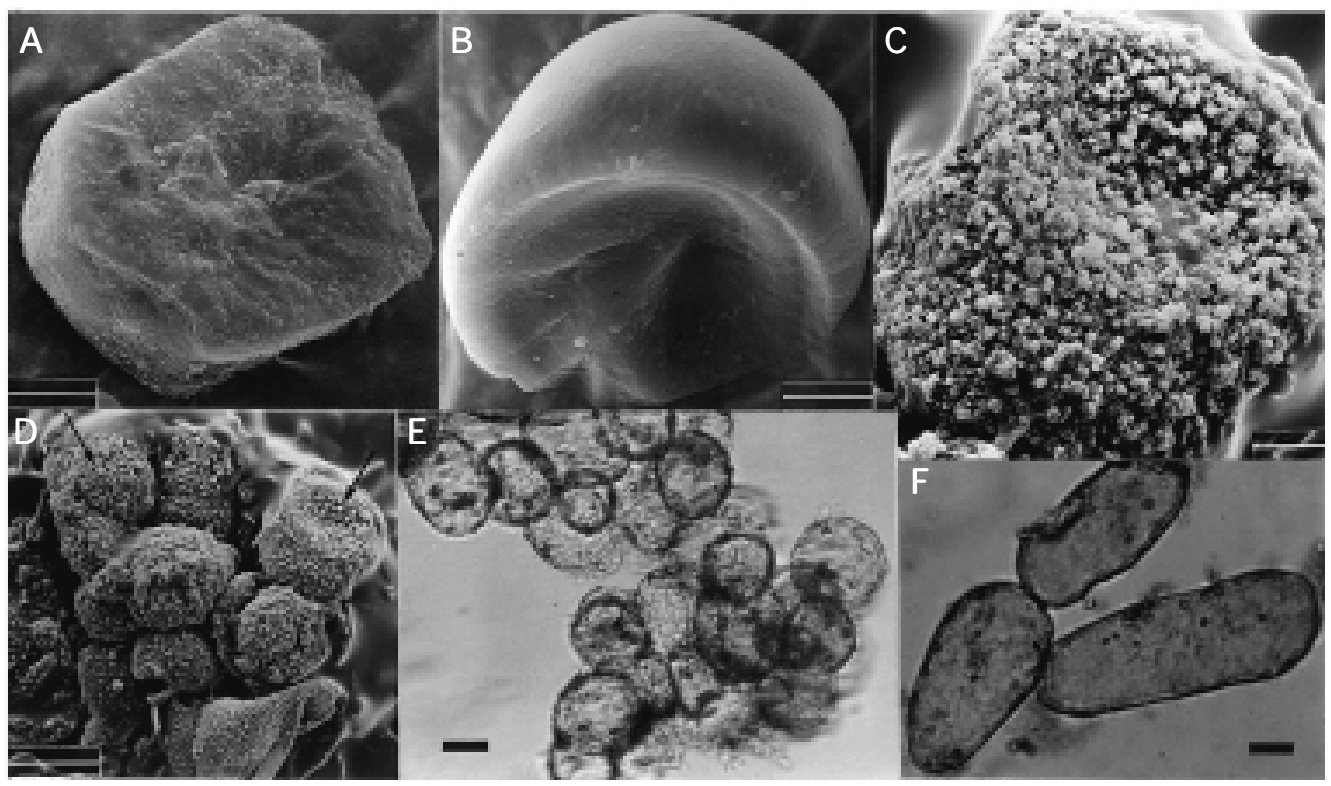

Figure 1. Scanning electron $(A$, $B, C$, and D) and light $(E, F)$ micrographs of Mandevilla velutina cultured cells showing variations in size, morphology and cell aggregates. A, B, Typical meristematic 7- and 21-day-old cells, respectively (bar $=5 \mu \mathrm{m})$. C, Details of the cell surface rugosity of a single cell (bar $=10 \mu \mathrm{m})$. D, Cell aggregates with the predominance of globular cell types from a 21-day-old culture. Arrows show the cell surface rugosity (bar $=50 \mu \mathrm{m})$. E, Sevenday-old cells (bar $=60 \mu \mathrm{m}$ ). F, Protein staining with $0.2 \%$ Coomassie brilliant blue R-250 in 21day-old cells showing an elongated shape (bar $=60 \mu \mathrm{m}$ ). 
Clearly green cell aggregates were usually observed, being formed only of meristematic cells (Figure 1D,E), with a mean range of 16-22 cells/aggregate. We observed a strong tendency to form larger cell aggregates when the cells were cultured in medium containing growth regulators at concentrations ten times lower than used in this study (data not shown). The size of the cell aggregates $(240-330 \mu \mathrm{m})$ is a determinant factor of culture behavior because of the different microenvironments to which the cells are exposed. It is also possible that such cells represent a variant phenotype with altered properties (26). Meaningful differences in cell surface rugosity were detected between single cells (Figures 1A-C and 2B) and cell aggregates (Figure 1D) along the culture stage. In fact, this trait seems to be useful for cell heterogeneity characterization in cultured plant cells, for clonal cell screening and for selection with polyclonal antibodies as biochemical markers (12). As a practical example, more recently the characterization of bacterial cells was performed



Figure 2. Light (A) and scanning electron (B) micrographs of 21-day-old Mandevilla velutina cells showing embryogenetic characteristics and specialized functions. A, Note the initial cell polarization (arrow). Bar $=15 \mu \mathrm{m}$. B, Smooth (S) and rough (R) areas on the proembryogenetic cell surface. Bar $=3 \mu \mathrm{m}$. C, Electron transmission micrograph showing a functional chloroplast containing starch-like granules. Bar $=400 \mathrm{~nm}$. by analyzing surface molecules (biomarkers) by mass spectrometry (MALDI-TOF), resulting in a mass fingerprint typical of the particular species, and in some cases at the strain level, demonstrating the feasibility of this approach (31).

Cells with embryogenetic characteristics (Figure 2A,B) were also found, suggesting the existence of this morphogenetic pathway. To the best of our knowledge, the occurrence of embryogenesis in cultured cells of $M$. velutina has not been previously reported. As M. velutina cultured cells express such a development after a callus stage, this seems to be a case of indirect embryogenesis which is the most common embryogenetic pathway. Previous analyses of M. velutina calli showed the occurrence of embryogenetic cells only in cultures older than 21 days. It seems that frequent subculturing (time intervals $<15$ days) inhibits this morphogenetic pathway, since embryogenetic cells were not found in these populations (32). Again, the existence of any differentiation stage in $M$. velutina cell suspension cultures demonstrated in the present work is interesting, considering that the focus is on the secondary metabolite synthesis (33).

The cultures were able to synthesize chlorophyll (data not shown), thus exhibiting a specialized function, and further transmission electron microscopy analysis (Figure 2C) showed the presence of chloroplasts exhibiting a normal architecture. This aspect is worth mentioning since the absence of specialized cell structures in some cultures may be a further reason for the absence or at least for much reduced levels of accumulated secondary metabolites (16). Chlorophyll content has been used as a parameter to evaluate the occurrence of variations in plant cell and tissue cultures $(30,34)$. In rye, as in other Gramineae, very frequent chlorophyll variations were observed in plants regenerated from immature embryo cultures (30). In Picea mariana and P. glauca, 0.1 and $0.3 \%$ of the plants regenerated by somatic em- 
bryogenesis were achlorophyllous and displayed different distributions and proportion of green and white tissues (variegata phenotype). However, chromosome number counts did not show differences between variegata and normal plants, emphasizing the fact that phenotypic evaluation seems to be a valuable tool to assess the genetic integrity of clonal propagation processes. Furthermore, in the absence of reliable genetic markers of somaclonal variation, phenotype still represents the easiest and fastest way to identify putative mutants (34).

The dissimilation curves observed are shown in Figure 3A,B. Cell cultures presented a variable growth index, suggesting the presence of somaclones with different metabolic rates in $M$. velutina cell suspension cultures. Similar results were found in semi-solid medium and in cell suspension culture kinetic experiments performed in the absence of light (12).

A detailed analysis of dissimilation curves for the cultures with the highest growth in$\operatorname{dex}\left(\mathrm{F}_{2}, \mathrm{~F}_{4}, \mathrm{~F}_{6}\right.$, and $\left.\mathrm{F}_{7}\right)$ revealed meaningful differences among them. The $\mathrm{F}_{2}$ cell population showed a typical sigmoid growth $\left(\mathrm{r}^{2}=\right.$ 0.996), with a lag and exponential phase duration of 4 and 14 days, respectively. This growth curve has been characteristic for $M$. velutina cell suspension cultures along the subcultures $(>30)$, with small variations, and we have considered it as a standard (hereafter referred to as control) for the purpose of further comparative analysis. $\mathrm{F}_{6}$ and $\mathrm{F}_{7}$ cell populations differed from the control $\left(\mathrm{F}_{2}\right)$ especially concerning lag phase duration (data not shown). A short lag phase ( 24 h) was observed for both populations and their growth phase was longer, 16 and 10 days, respectively. In fact, a mathematical model based on linear regression seems to better represent the dissimilation curve for the $\mathrm{F}_{7}$ cell line $\left(r^{2}=0.956\right)$, considering its lag and growth phase. High biomass-producing cell lines of Tabernaemontana divaricata cells displayed a similar profile for the growth curve with a short lag phase and also a linear growth phase, but without alterations in the alkaloid content (35). Furthermore, a mathematical treatment by integrating the area of each dissimilation curve revealed highest metabolic rates for $\mathrm{F}_{6}$ and $\mathrm{F}_{7}$ cell lines, which were 22.4 and $33.5 \%$ greater than the control $\left(\mathrm{F}_{2}\right)$, respectively, while $\mathrm{F}_{4}$ showed a dissimilation $15.9 \%$ lower than the control. Despite the differences for the cell cycle observed here, the maximum dissimilation at the stationary phase did not differ for these
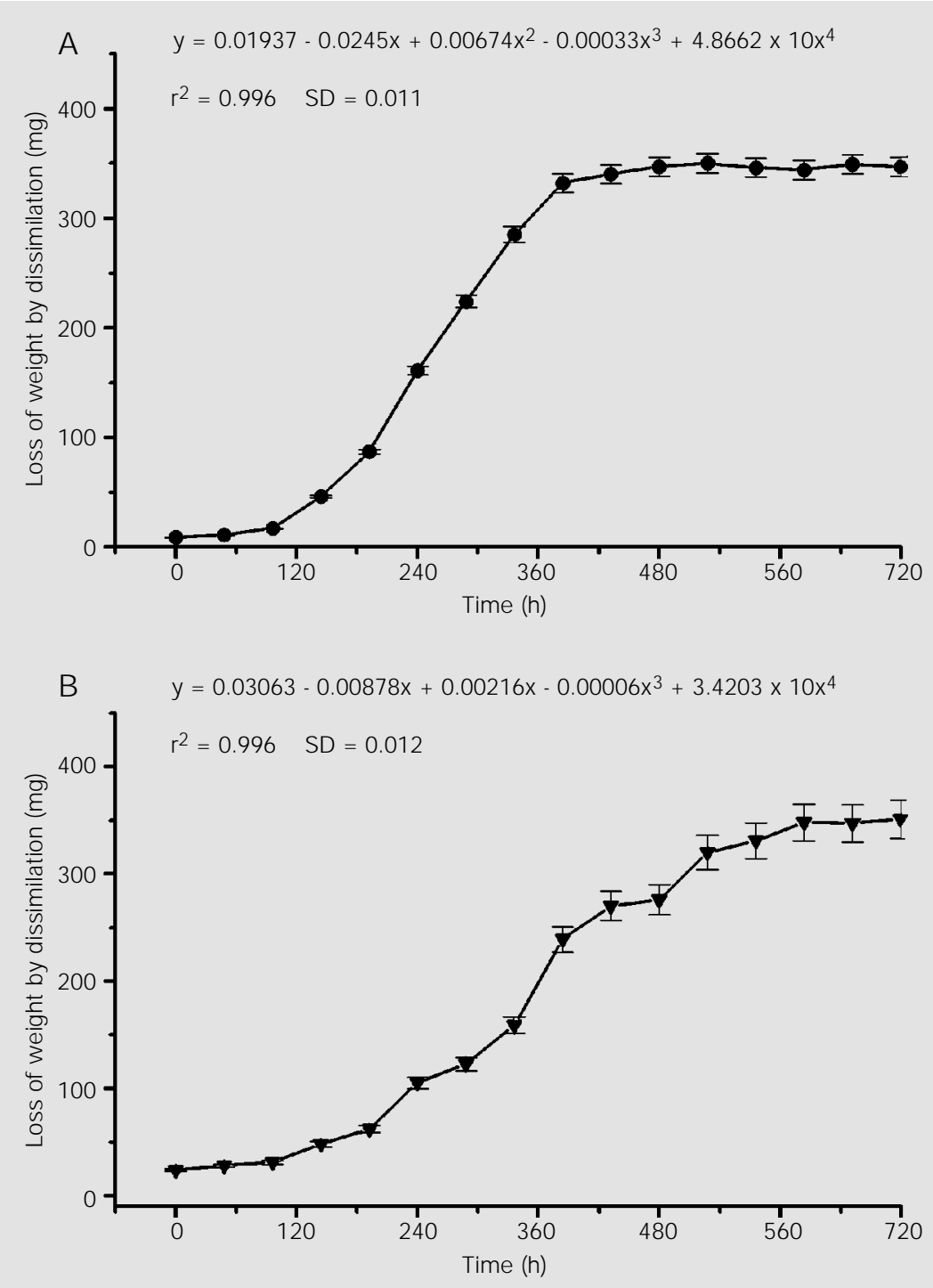

Figure 3. Representative dissimilation curve (A) for a Mandevilla velutina cell suspension culture showing a sigmoidal growth pattern $-F_{2}$ cell line. A distinct growth rate, with lower biomass accumulation, is shown in $(B)$ for the $F_{4}$ cell line $(P<0.05)$. 
three populations compared to the control $\left(F_{2}\right)$, with a mean value of about $356 \mathrm{mg}$ (25day-old cultures), suggesting a similar potential for biomass production. The cell suspension cultures with a lower growth rate $\left(F_{1}, F_{3}\right.$ and $\left.F_{5}\right)$ did not show cells with morphological changes that indicate degeneration or death.

Growth rate has been suggested as a criterion in experiments designed to select cell lines with higher performance (33). Indeed, one might consider it an expression of the genetic variability in cell cultures, which could be correlated with the synthesis rate of the metabolites of interest. Distinct dissimilation rates and indole alkaloid content were found in three $T$. divaricata cell strains along a culture period of nearly one year (36). The $\mathrm{N}$ strain accumulated a lot of intracellular glucose and fructose, with a relatively low dissimilation, whereas strain $\mathrm{S}$ behaved in the opposite manner and strain A showed an intermediate behavior. The highest indole alkaloid production content was found in strain $\mathrm{N}$, while strain A showed a lower but stable alkaloid production. No indole alkaloid production was detected in strain S. Interestingly, no evidence for random genetic instability was found in the experiments. Following this approach, thin layer chromatography analysis of the organosolvent fraction (ethyl acetate) extracted from
A

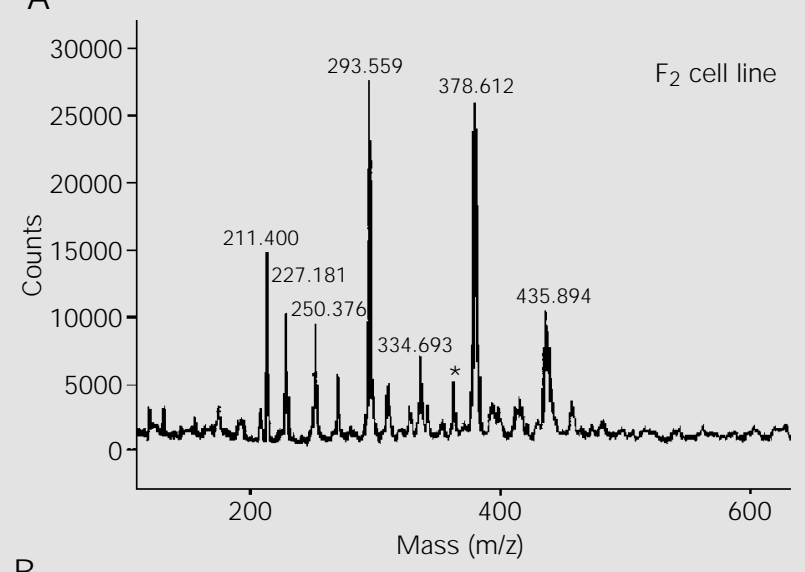

B

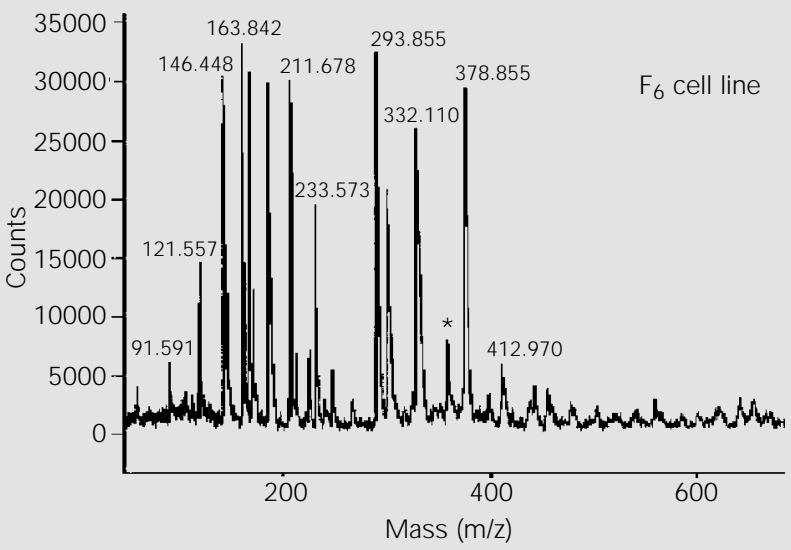

C

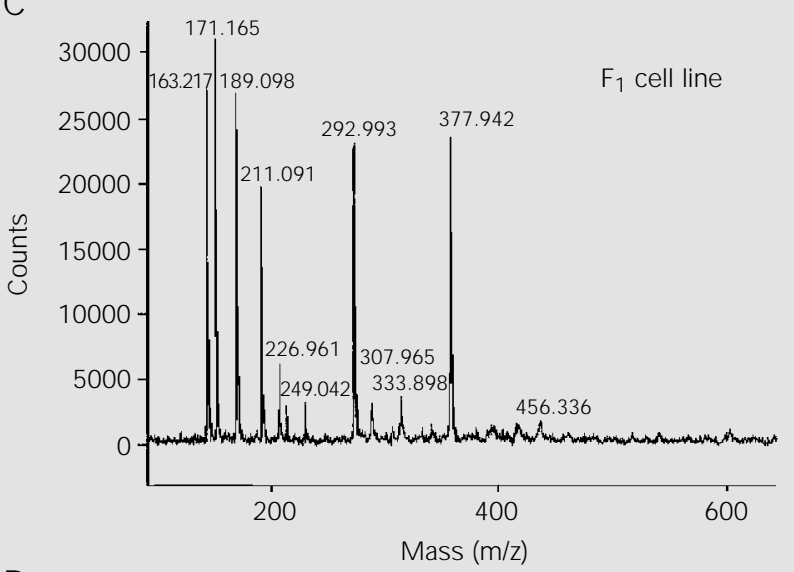

D

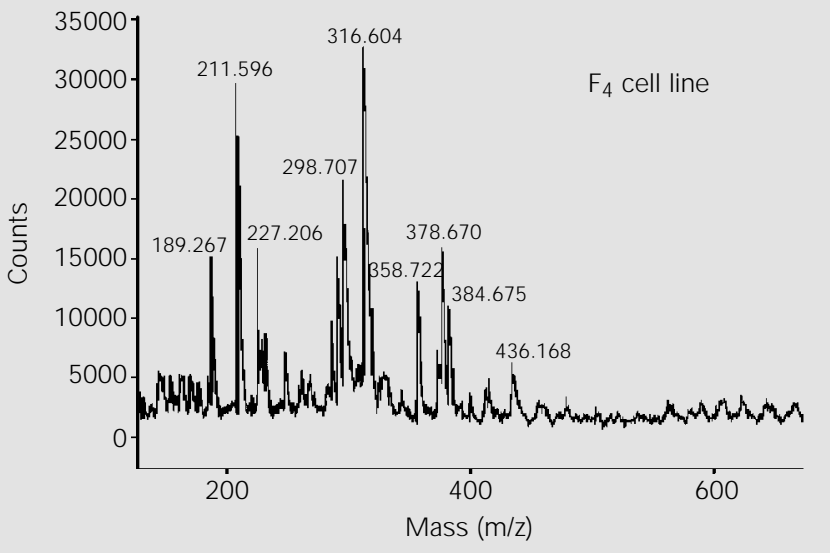

Figure 4. Partial, positive ion detection mode, MALDI-TOF mass spectrometry obtained from the ethyl acetate samples (crude extract) of producing and nonproducing cell lines of Mandevilla velutina. A, Producing $F_{2}$ cell line and $B$, producing $F_{6}$ cell line. The peak resulting from velutinol $A$ ( $m / z 362$ ) is marked with an asterisk. $C$, Nonproducing $F_{1}$ cell line and $D$, nonproducing $F_{4}$ cell line. Notice the absence of the peak resulting from velutinol $A(m / z=$ 362) in C and D. 
M. velutina cell cultures revealed distinct chromatographic patterns for the compounds of interest (i.e., MV 8608, velutinol $A$ and MV 8610, its glycosylated derivative - data not shown), indicating that some cell lines do not produce them. These findings prompted us to screen the cell lines selected according to their biomass yield in order to detect the compound of interest by using MALDI-TOF mass spectrometry with direct injection of the organosolvent samples into the mass spectrometer. For purposes of comparative analysis among cell lines with respect to velutinol $A$ production, the $\mathrm{F}_{5}$ cell line was used as control, as previously reported (24). Indeed, analysis of the MALDITOF spectra allowed us to confirm the chromatographic findings described above, pointing to the existence of velutinol $A$ producing (Figure 4A,B) and nonproducing (Figure $4 C, D)$ cell lines. Because of the soft ionization, MALDI mass spectrometry has been shown to be a robust technique for the analysis of compounds in the complex biological matrix of a crude plant extract, as shown for chlorinated bisbibenzyls in crude extracts of Bazzania trilobata (37). In a similar approach, MALDI-TOF mass spectrometry analysis of 3-deoxyanthocyanidins and anthocyanins was performed using crude extracts of Sorghum bicolor tissues, with sensitivities at $15 \mathrm{pmol} / \mu \mathrm{l}$ for 3-deoxyanthocyanidins and as low as $5 \mathrm{pmol} / \mu \mathrm{l}$ for pure samples of anthocyanidin (pelargonidin) and anthocyanin (malvin) (38). This approach would seem to be of interest in plant biotechnology programs for early identification and selection of high producing cell lines, reducing the duration of this usually time-consuming step, as well as for phytochemical studies, monitoring secondary metabolism in plant or animal cells and tissues, and for rapid and accurate characterization of microorganisms of interest $(24,31,37)$. Generally, a primary metabolite is synthesized as a direct result of the metabolic processes that keep the cells alive and growing and it accu- mulates in parallel with cell biomass. Conversely, a secondary metabolite is usually not formed as a direct result of metabolism that maintains cells in an actively dividing state and the accumulation of these metabolites tends to lag behind cell growth (16). Therefore, culture conditions favoring rapid growth are seldom considered as the best for the biosynthesis/accumulation of secondary metabolites. The present findings, especially considering the $F_{6}$ and $F_{7}$ cell lines, become interesting as one considers a two-stage strategy as a suitable way of increasing the productivity of plant cell cultures (39).

Since synchronous cell culture is an important tool for further studies of secondary metabolism, the results prompted us to pursue this goal. In preliminary attempts, growth analysis was carried out by determining the dissimilation curves for two independent cell populations and the results are shown in Figure 5A,B. A similar dissimilation profile
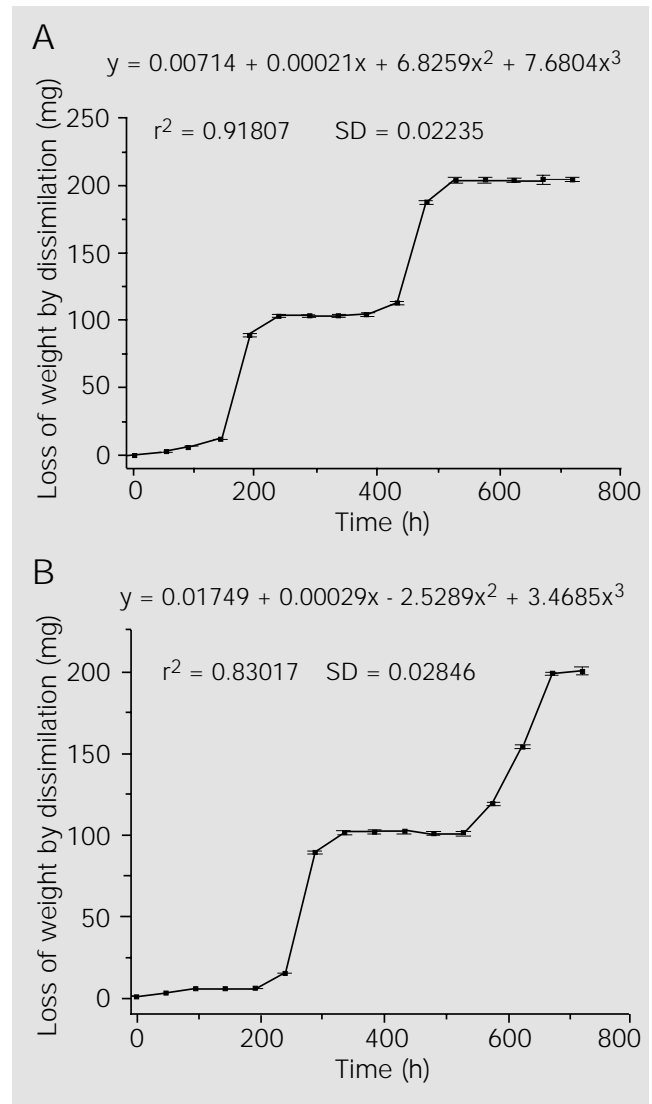

Figure 5. Loss of weight by dissimilation (mg) of two independent synchronous cell lines of Mandevilla velutina grown on $\mathrm{MC}_{24}$ semi-solid medium. The duration of the whole cell cycle (lag-stationary phase) is shown, being $288 \mathrm{~h}$ for the $S_{1}$ population $(\mathrm{A})$ and $384 \mathrm{~h}$ for the $\mathrm{S}_{2}$ population (B). $\mathrm{P}<0.05$ using the Student t-test. 
was observed for the cell populations in the time course experiments, which showed a synchronous cell cycle. This might be due to the cell harvesting time (30 days after inoculation - stationary phase), since it has been reported that the induction of synchronization of the cell cycle in cultures along the stationary phase can be due to lack of any nutrient (limiting factor). The elapsed time for the growth cycle (lag $\rightarrow$ stationary phase) was about 288 and $384 \mathrm{~h}$ for $\mathrm{S}_{1}$ and $\mathrm{S}_{2}$ populations, respectively. Accordingly, the total amount of dissimilation of the former cell population was somewhat higher $(35.3 \%)$ as calculated by integrating the area of its dissimilation curve.

The results point to a high cell variability present in the cultured cell populations with respect to morphogenetic and metabolic aspects. Furthermore, the findings are evidence that $M$. velutina cultured cells are heterogeneous in their ability to produce the compounds of interest, being mixtures of producing and nonproducing cells. Many plant cell cultures also exhibit variation in secondary product yield over successive subcultures. This phenomenon constitutes a poten- tial problem for the commercialization of fine chemical production by plant cell cultures, particularly when the instability takes the form of a consistent reduction in yield. One should keep in mind that unpredictable yield fluctuations of $50 \%$ or more might make all the difference between an interesting observation and a commercial process. Thus, it seems clear that the variation generated via the plant cell culture process could be interpreted as a hindrance to progress, for example, in an industrial program aiming at drug production from plant cell cultures. In this situation, however, this process of yield deterioration can be arrested by making selections at regular intervals, coupled to techniques scaled up to meet industrial production levels $(25,34)$. Since the somaclonal variation appears to provide an interesting approach to study secondary metabolism in order to select high producing cell lines, the performance of some producing velutinol $A$ cell lines herein described was screened in a two-stage cell culture system (38) in order to optimize the yield of this compound and the results will be published elsewhere.

\section{References}

1. Calixto J B, Strobel GH, Cruz AB \& Yunes RA (1988). Blockade of the bradykininevoked diphasic response of isolated rat duodenum by the crude extract of compounds obtained from Mandevilla velutina. Brazilian J oumal of Medical and Biological Research, 21: 1015-1018.

2. Bento ES, Calixto J B, Hawkes GE, Pizzolatti MG, Sant'Ana AEG \& Yunes RA (1996). The structure of velutinol $A$ is (15R, 16R, 20S)-14,16:15,20:16,21-triepoxy-15-16-seco-14ß,17 $\alpha$-pregn-5-ene3ß,15-diol. A combined quantitative Overhauser effect and molecular modelling study. J oumal of the Chemical Society. Perkin Transactions I, 2: 1359-1366.

3. Calixto J B, Silva AL, Reis MS, Costa RMBFL, Yunes J A, Cruz AB \& Yunes RA (1989). Demonstration of anti-bradykinin compounds in callus culture of Mandevilla velutina. Brazilian J ournal of Medical and
Biological Research, 22: 1275-1279.

4. Santos $A R$, Cruz $A B, M$ araschin $M$, Queiroz FP, Gorski F, Yunes RA \& Calixto J B (1992). Produção dos compostos ativos de Mandevilla velutina por cultura de tecidos in vitro. Análise química e farmacológica. In: Anais do XII Simpósio de Plantas Medicinais do Brasil, Universidade Federal do Paraná, Curitiba, PR, Brazil, September 1992, 75.

5. Bkaily G, Orleans PD, Calixto J B \& Yunes RA (1998). Patent No. CG 70857-228 Specific steady-state R-type $\mathrm{Ca}^{2+}$ channel blockers and used thereof. Canada, September 1998.

6. Maraschin M \& Queiroz FP (1991). Curva de crescimento de callus de Mandevilla velutina - Procedência Cerrado. In: Anais do III Encontro de Botânicos PR-SC, Universidade Federal de Santa Catarina, Florianópolis, SC, Brazil, October 1991, 33.
7. Petiard V, Baubault C, Bariaud A, Hutin M $\&$ Courtois D (1985). Studies on variability of plant tissue cultures for alkaloid production in Catharanthus roseus and $\mathrm{Pa}$ paver somniferum callus cultures. In: Neumann N (Editor), Primary and Secondary Metabolism of Plant Cell Cultures. Springer-Verlag, Berlin, Germany.

8. Scowcroft WR \& Larkin PJ (1988). Somaclonal variation. In: Bock $G \&$ Marsh J (Editors), Applications of Plant Cell and Tissue Culture. Ciba Foundation Symposium 137, J ohn Wiley and Sons, Chichester, England.

9. Hadi MZ \& Bridgen MP (1996). Somaclonal variation as a tool to develop pest resistant plants to Torenia foumieri 'Compacta Blue'. Plant Cell, Tissue and Organ Culture, 46: 43-50.

10. Scowcroft WR (1985). Somaclonal variation: The myth of clonal uniformity. In: 
Hohn B \& Dennis ES (Editors), Genetic Flux in Plants. Springer-Verlag, Vienna, Austria.

11. Skivin RM, MCPheeters KD \& Norton M (1994). Sources of frequency of somaclonal variation. Hortscience, 29: 12321237.

12. Maraschin M (1998). Variação somaclonal, metabolismo de carbono e caracterização bioquímica e imunológica nos cultivos celulares de Mandevilla velutina (MART) WOODSON (Apocynaceae). Master's thesis, Departamento de Bioquímica, Universidade Federal do Paraná, Curitiba, PR, Brazil.

13. Berlin J (1990). Screening and selection for variant cell lines with increased levels of secondary metabolites. In: Charlwood BV \& Rhodes MJC (Editors), Secondary Products from Plant Tissue Cultures. Clarendon Press, Oxford, England.

14. De Klerk GJ (1990). How to measure somaclonal variation. Acta Botanica Neerlandica, 39: 129-144.

15. Saunders J W, Acquaah G, Renner KA \& Doley WP (1992). Monogenic dominant sulfonylurea resistance in sugarbeet from somatic cell selection. Crop Science, 32: 1357-1360.

16. Mantell SH \& Smith H (1983). Cultural factors that influence secondary metabolite accumulations in plant cell and tissue cultures. In: Mantell SH \& Smith H (Editors), Plant Biotechnology. Cambridge University Press, Cambridge, England.

17. Fujita $Y$ (1988). Shikonin production by plant (Lithospermum erythrorhizon) cell cultures. In: Bajaj YPS (Editor), Biotechnology in Agriculture and Forestry: Medicinal and Aromatic Plants I. Vol. 4. Springer-Verlag, Berlin, Germany.

18. Fujita $Y \& \&$ Tabata M (1987). Secondary metabolites from plant cells: pharmaceutical applications and progress in commercial production. In: Somers DA, Hackett WP, Biesboer DD \& Green CE (Editors), Plant Tissue and Cell Culture. Alan R. Liss, Inc., New York, NY, USA.

19. Ushiyama K (1991). Large scale culture of ginseng. In: Komamine A, Misawa $M$ \& DiCosmo $\mathrm{F}$ (Editors), Plant Cell Culture in J apan. CMC, Tokyo, J apan.

20. Murashige T\& Skoog D (1962). A revised medium for rapid growth and bioassays with tobacco tissue cultures. Physiologia Plantarum, 15: 473-497.

21. George EF \& Sherrington PD (1984). Plant Propagation by Tissue Culture. Eastern Press, Reading, England, 12-22.

22. Schripsema J, Meyer $A H$, Iren $F$ van, Hoopen HJ G \& Verpoorte R (1990). Dissimilation curves as a simple method for the characterization of growth of plant cell suspension cultures. Plant Cell, Tissue and Organ Culture, 22: 55-64.

23. Yunes RA, Pizzolatti MG, Sant'Ana AEG, Hawkes GE \& Calixto J B (1993). The structure of Velutinol $A$, an anti-inflammatory compound with a novel pregnane skeleton. Phytochemical Analysis, 4: 76-81.

24. Maraschin $M$, Sugui J A, Wood KV, Bonham C, Lanças FM, Araujo PS, Yunes RA, Verpoorte R \& Fontana JD (2001). Supercritical $\mathrm{CO}_{2}$ extraction of velutinol $\mathrm{A}$ from Mandevilla velutina (Apocynaceae) cultured cells and MALDI-TOF MS analysis. Biotechnology Letters, 23: 77-82.

25. Stafford A (1986). Genetics of cultured plant cells. In: Morris P (Editor), Secondary Metabolism Plant Cell Culture. Cambridge University Press, Cambridge, England.

26. Ohta S \& Verpoorte R (1992). Some accounts of variation (heterogeneity and/or instability) in secondary metabolite production by plant cell cultures. Annual Report of Natural Science and Home Economics, 32: 9-23.

27. Bright $S$, J arret V, Nelson R, Creissen G, Karp A, Franklin J, Norbury P, Kueh J, Rognes S \& Miflin B (1983). Modification of agronomic traits using in vitro technology. In: Mantell SH \& Smith H (Editors), Plant Biotechnology. Cambridge University Press, New York, NY, USA

28. Phillips RL, Kaeppler SM \& Olhoft $P$ (1994). Genetic instability of plant tissue cultures: Breakdown of normal controls. Proceedings of the National Academy of Sciences, USA, 91: 5222-5226.

29. Meins J r F (1983). Heritable variation in plant cell cultures. Annual Review of Plant Physiology, 34: 327-346.

30. Linacero R \& Vázquez AM (1993). Somaclonal variation in rye. Mutation Research, 302: 205-210.

31. Welham KJ, Domin MA, Scannell DE, Cohen E \& Ashton DS (1998). The charac- terization of microorganisms by matrixassisted laser desorption/ionization timeof-flight mass spectrometry. Rapid Communications in Mass Spectrometry, 12: 176-180.

32. Fontana J D, Maraschin M, Buchi DF, Cantao MP, Tofol M, Peixoto ML \& Verpoorte R (1998). Cell heterogeneity and growth analysis of Mandevilla velutina (Apocynaceae) cultured cells. In: Proceedings of the 20th Symposium on Biotechnology for Fuels and Chemicals, Oak Ridge National Lab., Gatlinburg, TN, USA, May 1998, 63.

33. Verpoorte R (1990). The production of plant secondary metabolites. In: Dekkers J J , Plass HC van der \& Vuijk DH (Editors), Agricultural Biotechnology in Focus in the Netherlands. Pudoc, Wageningen, The Netherlands.

34. Tremblay L, Levasseur $C \&$ Tremblay FM (1999). Frequency of somaclonal variation in plants of black spruce (Picea mariana, Pinaceae) and white spruce (P. glauca, Pinaceae) derived from somatic embryogenesis and identification of some factors involved in genetic instability. American J ournal of Botany, 86: 1373-1381.

35. Sierra MI (1991). Aspects of indole alkaloid accumulation in Tabemaemontana tissue cultures: differentiation, peroxidases and stability. Doctoral thesis, Leiden University, Leiden, The Netherlands.

36. Schripsema J \& Verpoorte R (1992). Factors related to the indole alkaloid production in cell suspension cultures of Tabernaemontana divaricata. Planta Medica, 58: 245-249.

37. Speicher A, Hollemeyer $K \&$ Heinzle $E$ (2001). Rapid detection of chlorinated bisbibenzyls in Bazzania trilobata using MALDI-TOF mass spectrometry. Phytochemistry, 57: 303-306.

38. Sugui J A, Bonham C, Lo SC, Wood KV \& Nicholson RL (1998). MALDI-TOF analysis of mixtures of 3-deoxyanthocyanidins and anthocyanins. Phytochemistry, 48: 1063-1066.

39. Schlatmann J E (1995). Ajmalicine production by Catharanthus roseus. Process operation and modelling. Doctoral thesis, Tecnische Universiteit Delft, Delft, The Netherlands. 